\title{
Protective effects of a wheat germ rich diet against the toxic influence of profenofos on rat tissue lipids and oxidative pentose phosphate shunt enzymes
}

\author{
By G. A. Abdel-Rahim, ${ }^{a}$ and G. I. Mahmoud, ${ }^{\text {b* }}$ \\ ${ }^{a}$ Central Lab. Pest. Agric. Res. Center, Ministry of Agric. Giza, Egypt. \\ ${ }^{\mathrm{b}}$ Biochem., Dept., Fac. Agric., Cairo Univ., Giza, Egypt. \\ ( ${ }^{*}$ Corresponding author: ghadaibraheim @ yahoo.com)
}

\section{RESUMEN}

Efecto protector de dietas ricas en germen de trigo contra la influencia tóxica de profenofós en lípidos de tejido de rata y en enzimas de la via de la pentosa fosfato.

El efecto de formas técnicas o formuladas de profenofós en la fracción lipídica metabólica de hígado, cerebro y riñones así como la actividad de la glucosa-6-fosfato deshidrogenasa (G6PD) y 6-fosfogluconato deshidrogenasa (6PGD), que son consideradas enzimas relacionadas con los lípidos, fueron estudiadas. Ambas formas de profenofós fueron suministradas separadamente tanto por vía oral como cutánea a una dosis de $1 / 20 L_{50}$ durante 3 meses (una dosis cada 48 horas). Los lípidos totales y fracciones lipídicas (contenido de colesterol, triglicéridos y fosfolípidos) decrecieron en los tres órganos estudiados de ratas tratadas con profenofós tanto técnicos como formulado comparado con animales control. El mayor efecto fue observado en el caso de tratamientos orales con profenofós formulados, mientras que el más bajo fue detectado para el tratamiento cutáneo con profenofós técnicos. La misma tendencia fue encontrada en las actividades de G6PD y 6PGD asociadas con el metabolismo lipídico de tejidos de hígado, cerebro y riñón bajo las mismas condiciones. Por otra parte, animales tratados con profenofós y alimentados con una dieta rica en germen de trigo (como agente antioxidante) produjo una significativa mejora tanto en el contenido de las fracciones lipídicas como en la actividad enzimática. Es más, el efecto de dietas ricas en germen de trigo (fuente rica de $\alpha$-tocoferol) reajustó y mejoró el trastorno metabólico del perfil lipídico de las fracciones en ratas tratadas con profenofós, así como su actividad enzimática relacionada (G6PD y 6PGD: via oxidativa de las pentosas fosfato).

PALABRAS CLAVE: Germen de trigo - Perfil lipídico Profenofós - Ratas.

\section{SUMMARY}

Protective effects of a wheat germ rich diet against the toxic influence of profenofos on rat tissue lipids and oxidative pentose phosphate shunt enzymes.

The effects of technical and formulated forms of profenofos on the metabolic lipid fractions of the liver, brain and kidneys as well as the activity of glucose-6-phosphate dehydrogenase (G6PD) and 6-phosphogluconate dehydrogenase (6PGD), which consider lipid related enzymes, were studied. The two forms of profenofos were given separately either orally or by dermal at doses of $1 / 20 L_{50}$ for 3 months (one dose every 48 h). Total lipids and lipid fractions (cholesterol, triglycerides and phospholipid contents) decreased in the three studied organ tissues either in technical or formulated profenofos-induced rats compared with normal control animals. The highest effect was observed in the case of orally formulated profenofo induction, and the lowest was detected for the dermal technical one. The same trend was found in the activities of G6PD and 6PGD associated with lipid metabolism in the liver, brain and kidney tissues under the same conditions. On other hand, the treatment of profenofos-induced animals by feeding a wheat germ rich diet (as antioxidant agent) produced significant improvements in both lipid fraction content and enzyme activity. In addition, the effects of the wheat germ rich diet ( $\alpha$-tocopherol rich source) readjusted and improved the disturbed metabolic fractions of the lipid profiles in the profenofos-induced rats as well as their related enzyme activities (G6PD and 6PGD: oxidative pentose phosphate shunt)

KEY-WORDS: Lipids profile - Profenofos - Rats - Wheat germ.

\section{INTRODUCTION}

Profenofos is employed as an organophosphorus insecticide in the keeping and growing of agricultural products. Organophosphate pesticides have been in use for over 50 years and their acute toxicity is relatively well understood, but chronic low-level exposure to these pesticides has been implicated as a causal factor in a variety of different forms of human ill-health (COT, 1999 and Ray and Richards, 2001). Organophosphorus insecticides (OPI) are widely used throughout the world for the control of agricultural and domestic insect pests because of their low persistence and easily biodegradable nature. The use of this class of insecticides has resulted in worldwide increases in food and fiber production, along with the control of major disease carrying vectors and structure damaging insect pests (Grover et al., 2003). Contamination of food occurs from contact with pesticide-laden surfaces, thus increasing the potential for excess dietary exposure of children and adults (Rohrer et al., 2003). Profenofos, as an organophosphorus insecticide, shows its effect directly by inhibiting the 
acetycholinesterase enzyme (USEPA, 2000). Profenofos affects the antioxidant system, which plays an important role in making xenobiotics entering the body infective. The basic reason for this effect is that profenofos is made with glutathione-S-transferase (GST) which is an essential enzyme in the detoxification of the antioxidant system. Decreasing the detoxification process leads to the accumulation of harmful metabolites and parallel to this, it inevitably causes cytotoxic and genotoxic incidents. Some changes observed in enzyme activities can sometimes be brought under control thanks to vitamins (Abdel-Rahman et al., 2006; Verma et al., 2007 and Goel et al., 2005 and 2007).

Oral et al. (2006) and Verma et al. (2007) applied vitamin E, A and C for dichlorvos and chlorpyrifos toxicities in rats. Also, our previous studies applied these vitamins for chlorpyrifos, dimethoate and profenofos intoxicated rats to attenuate the pesticide perturbation in albino rats (Abdel-Rahim and Abdel-Rahim, 2007, 2008 and Abdel-Rahim 2009). The most detected tissues are cytosol and the membranes of many organs such as the brain and kidneys, but especially the liver (Hayes et al., 2005). The involvement of oxidative stress following acute exposure to OPI has demonstrated unequivocally that lipid peroxidation is one of the molecular mechanisms involved in OPI-induced toxicity (Abdollahi et al., 2004). Accordingly, interest has recently grown in the role and use of natural antioxidants as a strategy to prevent oxidative damage in various health disorders with oxidative stress (Coskum et al., 2005). Natural antioxidants from plants are reported to provide substantial protection that slows down the process of oxidative damage caused by ROS (Jacob and Burri, 1996). Hence there has been growing interest in natural antioxidants of plant origin since they also find use as nutraceuticals due to their impact on the status of human health and disease prevention (Noguchi and Nikki, 2000).

Vitamin E (a fat soluble vitamin) is used to describe isomers of tocopherol and tocotrienol that qualitatively exhibit the biological activity of $\alpha$-tocopherol. The antioxidant activity of tocopherols is well documented (Ohkatsu et al., 2001). One physiological role of vitamin $E$ is its ability to react with and quench free radicals in cell membranes and other lipid environments, thereby preventing polyunsaturated fatty acids (PUFA) from oxidation. Wheat germ, a by-product of the flour milling industry and the oil extracted from wheat germ are the richest known natural dietary sources of tocopherols (vitamin E) of plant origin (Piras et al., 2009). Leenhardt et al. (2008) showed that wheat germ and wheat germ oil intake results in a rapid increase in the content of vitamin $\mathrm{E}$ in different rat tissues and a change in the intensity of lipid peroxidation processes.

The aim of the present study was to evaluate the biochemical perturbations induced by profenofos in rat lipid profiles as well as the oxidative pentose phosphate shunt of liver, brain and kidneys tissues and to determine the protective effects of the administration of wheat germ rich diet ( $\alpha$-tocopherol and other antioxidant) against the above effects induced by profenofos.

\section{MATERIALS AND METHODS}

\subsection{Materials}

Profenofos (O-(4-bromo-2-chlorophenyl)-Oethyl-S-propyl phosphorothioate) forms, technical $\left(95 \%\right.$ a.i) and formulated (72\% E.C.) of $\mathrm{LD}_{50}: 358$ $\mathrm{mg} / \mathrm{kg}$ rat body weight for oral dose, and $3300 \mathrm{mg} /$ $\mathrm{kg}$ rat body weight for dermal dose (Tomlin, 2000) were provided by Central Agricultural Pesticides Laboratory, Agriculture Research Center, Dokki, Giza, Egypt.

Wheat germ was obtained from South Cairo and Giza flour Mills and Bakeries Company, Cairo, Egypt. It came as a dried crushed sample. The crushed wheat germ was pulverized with a blender to a fine powder and kept until use. Vitamin $E$ was determined in wheat germ colorimetrically according to the method obtained by Fisher et al. (1964).

\subsection{Animals and Experimental Design}

Sixty healthy adult male albino rats (Rattus Noruegicus) Sprague Dawlay strain each weighing about $120 \pm 5 \mathrm{~g}$ were raised in the animal house of the Central Agricultural Pesticides Laboratory, Dokki, Giza, Egypt. The animals were kept under normal healthy laboratory conditions (temperature was set at $25 \pm 2^{\circ} \mathrm{C}$ with relative humidity of $\approx 57 \%$ and 12-hour light-dark cycle) for two weeks in their cages prior to the experiment for acclimatization. During this period, rats were fed a normal diet which consisted of casein $15 \%$, cotton seed oil $10 \%$, cellulose $5 \%$, salt mixture $4 \%$, vitamins mixture $1 \%$ and starch $65 \%$ (Lane-Peter and Pearson, 1971). Rats were allowed free diet and water (ad libitum). Rats were divided into 10 groups (6 rats each). Five groups were fed the normal diet and the other five groups were fed the normal diet supplemented with $20 \%$ wheat germ (wheat germ rich diet) as a source of $\alpha$-Tocopherol. The first group was fed the normal diet without any supplementation which served as the normal control. The second group was fed the wheat germ rich diet. The $3^{\text {rd }}$ and $5^{\text {th }}$ groups were ingested respectively with a sublethal dose of either the technical or formulated profenofos (1/20 of oral $\mathrm{LD}_{50}$ ) and fed the normal diet. The same treatments were done with the $4^{\text {th }}$ and $6^{\text {th }}$ groups respectively but these animals were fed the wheat germ rich diet (the oral doses of the pesticide were ingested through a stomach tube). The $7^{\text {th }}$ and $9^{\text {th }}$ groups were treated with the dermal sublethal dose of technical or formulated profenofos (1/20 of dermal $\left.L_{50}\right)$ respectively, and fed the normal diet. The 
same treatments were done with the $8^{\text {th }}$ and $10^{\text {th }}$ groups respectively but these animals were fed the wheat germ rich diet.

For the dermal treatment, the application of dorsal skin was as follows: one day before dosing, an area of $2 \times 2 \mathrm{~cm}$ on the back of the dermally treated rats was shaved with care not to abrade the skin. The shaved area was washed with acetone. The doses were then applied evenly and carefully on the shaved area skin (Abou-Zeid et al., 1993). Technical or formulated profenofos was used without any additives for dermal treatment. For oral ingestion the pesticide was emulsified with $0.5 \mathrm{ml}$ distilled water. One dose was inducted every 48 hours during the experimental period (three months), either for oral or dermal administration of both forms of profenofos. Diets (normal diet or wheat germ rich diet) and water were supplied ad libitum.

At the end of experimental period (three months), the rats were killed by decapitation. Liver, brain and kidneys of all experimental animals were removed and chilled until analysis. The three organs were homogenated separately before analysis.

\subsection{Biochemical Analysis}

Total lipids, cholesterol, triglycerides and phospholipid contents in the homogenate of the studied organ tissues were determined by the methods of Joseph et al. (1972), Chaurchami et al. (1959), Young and Pestaner (1975) and Ketes (1972), respectively. Total soluble proteins in the homogenates were determined according to Bradford (1976) methods. The activity of glucose6-phosphate dehydrogenase (G6PD: EC. 1.1.1.49) and 6-phosphogluconate dehydrogenase (6PGD: EC. 1.1.1.43) was determined in the homogenates of the different organs tissues according to the method of Glock and McLean (1953).

\subsection{Statistical Analysis}

All data are expressed as mean \pm standard deviation. The data was analyzed by the analysis of variance (ANOVA). Testing of mean values in different groups was done by Duncan's multiple range test. SPSS 10 window version was used for the statistical analysis (Middle Brooks, 1977).

\section{RESULTS AND DISCUSSION}

The effects of different forms of profenofos pesticide induction into adult male albino rats on total lipids, cholesterol, triglycerides and phospholipid contents in the liver, brain and kidneys were determined and the results of normal and profenofos-induced animals are recorded in Tables 1 to 4 . In connection, the activity of G6PD and 6PGD (oxidative pentose phosphate shunt enzymes) was also determined in the three organ tissues under the same conditions as shown in Tables 5 and 6 . In the case of the wheat germ (containing 27.38mg vitamin E/100g) rich diet feeding for profenofos-induced rats, the lipids profile and also the activity of G6PD and 6PGD of liver, kidneys and brain were carried out to evaluate the hypointensive influences of wheat germ used as an antagonistic agent on the effect of profenofos.

The present results (Tables 1 and 2) showed that both forms of profenofos (technical and formulated) inductions lowered total lipids and total cholesterol contents in the subjected rat tissues relative to that of the normal control animals. The formulated pesticide induced orally was more effective than the other induction, but the induction of the technical formulation dermally had the lowest effects. Among the organs studied, the kidneys were characterized by the highest decreases in total lipid and cholesterol contents but for the liver and brain, the total lipid and cholesterol contents showed the same trend and decreased to slightly lower than the kidneys of profenofos-induced animals under the same conditions. The feeding of the wheat germ rich diet improved the values of the total lipid contents of the liver, brain and kidney tissues of profenofosinduced animals and returned these values to around that of the normal value of the healthy control. The same trend was observed in the case of total cholesterol content of the same organs tissues, feeding the wheat germ rich diet decreased the harmful effects of different forms of profenofos and the content of total cholesterol was alleviated, in the liver, brain and kidney tissues.

In addition, both forms of profenofos (technical and formulated) separately induced by dermal or orally showed significant decreases in total triglycerides and phospholipid contents of the three examined tissues (Tables 3 and 4). However, the kidneys were also characterized by a relatively higher decrease than those of the liver and brain for triglyceride contents under the same conditions in profenofos-induced animals; while the brain was characterized by a high decrease in phospholipid content. On the other hand, the relative percent decreases of the above constituents (total lipids, cholesterol, triglycerides and phospholipids) in the other organs produced nearly the same figures. These decreased values were improved by feeding the wheat germ rich diet. This means that wheat germ (mainly $\alpha$-tocopherol antioxidant) reduced the harmful effects of the present pesticide in the three organ tissues.

In connection, Tables 5 and 6 show that significant inhibition had occurred in the G6PD and 6PGD activities of the liver, kidneys and brain tissues affected by profenofos induction. It is of interest to note that the liver was characterized by higher G6PD activity than the other organs during the experimental period; whereas that of the kidneys showed the highest inhibition compared to those of liver and brain relative to the control. The 
Table 1

The total lipid contents in different organ tissues of the experimental male albino rats

\begin{tabular}{|c|c|c|c|c|c|c|}
\hline \multirow{3}{*}{ Treatments } & \multicolumn{6}{|c|}{ Total lipids (g/100g) } \\
\hline & \multicolumn{2}{|l|}{ Liver } & \multicolumn{2}{|l|}{ Brain } & \multicolumn{2}{|c|}{ Kidneys } \\
\hline & Values \pm SD & $\%$ & Values \pm SD & $\%$ & Values \pm SD & $\%$ \\
\hline Normal healthy control & $3.99 \pm 0.17^{a}$ & 100 & $4.35 \pm 0.20^{a}$ & 100 & $3.61 \pm 0.14^{\mathrm{a}}$ & 100 \\
\hline Normal healthy + wheat germ & $4.01 \pm 0.19^{a}$ & 101 & $4.40 \pm 0.21^{\mathrm{a}}$ & 101 & $3.59 \pm 0.14^{\mathrm{a}}$ & 99 \\
\hline \multicolumn{7}{|l|}{ Oral } \\
\hline Technical P & $3.21 \pm 0.14^{b}$ & 80 & $3.46 \pm 0.16^{c}$ & 80 & $2.80 \pm 0.13^{c}$ & 78 \\
\hline Technical + wheat germ & $3.81 \pm 0.15^{a}$ & 95 & $4.11 \pm 0.17^{\mathrm{ab}}$ & 94 & $3.40 \pm 0.12^{a}$ & 94 \\
\hline Formulated P & $2.88 \pm 0.19^{c}$ & 72 & $3.00 \pm 0.13^{d}$ & 69 & $2.52 \pm 0.11^{d}$ & 70 \\
\hline Formulated $\mathrm{P}+$ Wheat germ & $3.70 \pm 0.18^{a}$ & 93 & $4.00 \pm 0.12^{b}$ & 92 & $3.14 \pm 0.10^{b}$ & 87 \\
\hline \multicolumn{7}{|l|}{ Dermal } \\
\hline Technical P & $3.80 \pm 0.14^{a}$ & 95 & $3.71 \pm 0.18^{c}$ & 85 & $2.86 \pm 0.10^{c}$ & 79 \\
\hline Technical P + wheat germ & $3.91 \pm 0.17^{a}$ & 98 & $4.24 \pm 0.19^{a b}$ & 97 & $3.44 \pm 0.12^{a}$ & 95 \\
\hline Formulated P & $3.19 \pm 0.13^{b}$ & 80 & $3.50 \pm 0.16^{c}$ & 80 & $3.00 \pm 0.13^{b c}$ & 83 \\
\hline Formulated P + wheat germ & $3.82 \pm 0.14^{a}$ & 96 & $4.10 \pm 0.17^{\mathrm{ab}}$ & 94 & $3.60 \pm 0.14^{a}$ & 100 \\
\hline$L S D$ & 0.276 & & 0.292 & & 0.208 & \\
\hline
\end{tabular}

$\mathrm{P}=$ Pesticide (Profenofos). \% relative to normal healthy control. Values are expressed as means $\pm S D(n=6)$.

Values with different superscript letters within the same column are significantly different $(P<0.05)$.

activity of 6PGD had shown a similar trend to G6PD in the three organ tissues under the same conditions. However, profenofos inhibited the activity of G6PD and 6PGD in tissue homogenates either in the form of technical or formulated. Among the organs studied, the kidneys were characterized by the highest G6PD and 6PGD inhibition activities but the liver and brain had lower inhibition than the kidneys under the induced effects of profenofos. The inhibited activities of G6PD and 6PGD of the

Table 2

The total cholesterol content in different organ tissues of the experimental male albino rats

\begin{tabular}{|c|c|c|c|c|c|c|}
\hline \multirow{3}{*}{ Treatments } & \multicolumn{6}{|c|}{ Total cholesterol (mg/100g) } \\
\hline & \multicolumn{2}{|l|}{ Liver } & \multicolumn{2}{|l|}{ Brain } & \multicolumn{2}{|c|}{ Kidneys } \\
\hline & Values \pm SD & $\%$ & Values \pm SD & $\%$ & Values \pm SD & $\%$ \\
\hline Normal healthy control & $250 \pm 20^{a}$ & 100 & $1821 \pm 117^{\mathrm{a}}$ & 100 & $331 \pm 30^{a}$ & 100 \\
\hline Normal healthy + wheat germ & $256 \pm 21^{a}$ & 102 & $1827 \pm 125^{a}$ & 100 & $330 \pm 28^{a}$ & 100 \\
\hline \multicolumn{7}{|l|}{ Oral } \\
\hline Technical P & $210 \pm 19^{b c}$ & 84 & $1585 \pm 110^{b c}$ & 87 & $271 \pm 21^{\text {cde }}$ & 82 \\
\hline Technical + wheat germ & $231 \pm 14^{\mathrm{abc}}$ & 92 & $1771 \pm 132^{\mathrm{ab}}$ & 97 & $301 \pm 14^{\mathrm{abc}}$ & 91 \\
\hline Formulated P & $201 \pm 13^{c}$ & 80 & $1501 \pm 101^{c}$ & 82 & $240 \pm 11^{\mathrm{e}}$ & 73 \\
\hline Formulated $\mathrm{P}+$ Wheat germ & $225 \pm 17^{a b c}$ & 90 & $1750 \pm 124^{\mathrm{ab}}$ & 96 & $294 \pm 13^{b c d}$ & 89 \\
\hline \multicolumn{7}{|l|}{ Dermal } \\
\hline Technical P & $215 \pm 19^{b c}$ & 86 & $1594 \pm 108^{\mathrm{bc}}$ & 88 & $301 \pm 15^{\mathrm{abc}}$ & 91 \\
\hline Technical P + wheat germ & $240 \pm 20^{a b}$ & 96 & $1800 \pm 111^{\mathrm{ab}}$ & 99 & $319 \pm 14^{\mathrm{ab}}$ & 96 \\
\hline Formulated P & $211 \pm 18^{\mathrm{bc}}$ & 84 & $1580 \pm 119^{b c}$ & 87 & $267 \pm 12^{\text {de }}$ & 81 \\
\hline Formulated $\mathrm{P}+$ wheat germ & $234 \pm 21^{a b c}$ & 94 & $1785 \pm 125^{a b}$ & 98 & $300 \pm 12^{a b c}$ & 91 \\
\hline$L S D$ & 31.36 & & 200.67 & & 30.55 & \\
\hline
\end{tabular}

$P=$ Pesticide (Profenofos). \% relative to normal healthy control. Values are expressed as means $\pm S D(n=6)$.

Values with different superscript letters within the same column are significantly different $(P<0.05)$. 
Table 3

The total triglyceride contents in different organ tissues of the experimental male albino rats

\begin{tabular}{|c|c|c|c|c|c|c|}
\hline \multirow{3}{*}{ Treatments } & \multicolumn{6}{|c|}{ Total triglycerides $(\mathrm{g} / \mathbf{1 0 0 g})$} \\
\hline & \multicolumn{2}{|l|}{ Liver } & \multicolumn{2}{|l|}{ Brain } & \multicolumn{2}{|c|}{ Kidneys } \\
\hline & Values \pm SD & $\%$ & Values \pm SD & $\%$ & Values \pm SD & $\%$ \\
\hline Normal healthy control & $2.00 \pm 0.17^{\mathrm{a}}$ & 100 & $2.14 \pm 0.17^{\mathrm{ab}}$ & 100 & $1.86 \pm 0.13^{a}$ & 100 \\
\hline Normal healthy + wheat germ & $2.07 \pm 0.24^{a}$ & 104 & $2.20 \pm 0.16^{\mathrm{a}}$ & 103 & $1.88 \pm 0.14^{\mathrm{a}}$ & 101 \\
\hline \multicolumn{7}{|l|}{ Oral } \\
\hline Technical P & $1.61 \pm 0.11^{\mathrm{bcd}}$ & 81 & $1.80 \pm 0.12^{\mathrm{cd}}$ & 84 & $1.41 \pm 0.11^{\mathrm{cd}}$ & 76 \\
\hline Technical + wheat germ & $1.91 \pm 0.10^{\mathrm{a}}$ & 96 & $2.01 \pm 0.17^{\mathrm{abcd}}$ & 94 & $1.71 \pm 0.12^{a b}$ & 92 \\
\hline Formulated P & $1.52 \pm 0.12^{d}$ & 76 & $1.51 \pm 0.10^{\mathrm{e}}$ & 71 & $1.27 \pm 0.10^{d}$ & 68 \\
\hline Formulated $\mathrm{P}+$ Wheat germ & $1.84 \pm 0.14^{\mathrm{ab}}$ & 92 & $1.98 \pm 0.14^{\mathrm{abcd}}$ & 93 & $1.58 \pm 0.13^{b c}$ & 85 \\
\hline \multicolumn{7}{|l|}{ Dermal } \\
\hline Technical P & $1.80 \pm 0.12^{\mathrm{abc}}$ & 90 & $1.86 \pm 0.13^{\mathrm{bcd}}$ & 87 & $1.50 \pm 0.12^{b c}$ & 81 \\
\hline Technical P + wheat germ & $1.92 \pm 0.11^{\mathrm{a}}$ & 96 & $2.13 \pm 0.16^{\mathrm{ab}}$ & 100 & $1.72 \pm 0.11^{\mathrm{ab}}$ & 92 \\
\hline Formulated P & $1.58 \pm 0.13^{\mathrm{cd}}$ & 79 & $1.76 \pm 0.14^{\mathrm{de}}$ & 82 & $1.43 \pm 0.13^{\mathrm{cd}}$ & 77 \\
\hline Formulated P + wheat germ & $1.89 \pm 0.12^{\mathrm{a}}$ & 95 & $2.06 \pm 0.16^{\mathrm{abc}}$ & 96 & $1.81 \pm 0.12^{\mathrm{a}}$ & 97 \\
\hline$L S D$ & 0.239 & & 0.255 & & 0.203 & \\
\hline
\end{tabular}

$P=$ Pesticide (Profenofos). \% relative to normal healthy control. Values are expressed as means $\pm S D(n=6)$.

Values with different superscript letters within the same column are significantly different $(P<0.05)$.

profenofos-induced rats were ameliorated by feeding the wheat germ rich diet. The results clearly show that both forms (technical and formulated) of profenofos ingestion had a disturbed effect on the activity of oxidative pentose phosphate shunt enzymes (G6PD and 6PGD) in the three rat organ tissues of the profenofos-induced animals, but the wheat germ rich diet improved these effects.

The present results are in agreement with Lukaszewicz-Hussain and Moniuszko-Jakoniuk

Table 4

The total phospholipid contents in different organ tissues of the experimental male albino rats

\begin{tabular}{|c|c|c|c|c|c|c|}
\hline \multirow{3}{*}{ Treatments } & \multicolumn{6}{|c|}{ Total phospholipids (g/100g) } \\
\hline & \multicolumn{2}{|l|}{ Liver } & \multicolumn{2}{|l|}{ Brain } & \multicolumn{2}{|l|}{ Kidneys } \\
\hline & Values \pm SD & $\%$ & Values \pm SD & $\%$ & Values \pm SD & $\%$ \\
\hline Normal healthy control & $1.00 \pm 0.08^{a}$ & 100 & $1.19 \pm 0.11^{\mathrm{a}}$ & 100 & $0.87 \pm 0.05^{\mathrm{a}}$ & 100 \\
\hline Normal healthy + wheat germ & $1.02 \pm 0.10^{\mathrm{a}}$ & 102 & $1.20 \pm 0.10^{a}$ & 101 & $0.90 \pm 0.05^{a}$ & 103 \\
\hline \multicolumn{7}{|l|}{ Oral } \\
\hline Technical P & $0.80 \pm 0.06^{c d}$ & 80 & $0.91 \pm 0.07^{c d}$ & 76 & $0.71 \pm 0.04^{\mathrm{cd}}$ & 82 \\
\hline Technical + wheat germ & $0.91 \pm 0.08^{a b c}$ & 91 & $1.00 \pm 0.06^{\mathrm{bcd}}$ & 84 & $0.85 \pm 0.05^{a b}$ & 98 \\
\hline Formulated P & $0.77 \pm 0.04^{d}$ & 77 & $0.73 \pm 0.04^{\mathrm{e}}$ & 61 & $0.64 \pm 0.04^{d}$ & 74 \\
\hline Formulated $\mathrm{P}+$ Wheat germ & $0.86 \pm 0.06^{\mathrm{bcd}}$ & 86 & $0.98 \pm 0.06^{\mathrm{bcd}}$ & 82 & $0.77 \pm 0.07^{\mathrm{bc}}$ & 89 \\
\hline \multicolumn{7}{|l|}{ Dermal } \\
\hline Technical P & $0.90 \pm 0.07^{\mathrm{abcd}}$ & 90 & $0.94 \pm 0.07^{\mathrm{cd}}$ & 79 & $0.74 \pm 0.06^{c}$ & 85 \\
\hline Technical P + wheat germ & $0.95 \pm 0.08^{a b}$ & 95 & $1.08 \pm 0.06^{\mathrm{ab}}$ & 91 & $0.87 \pm 0.05^{\mathrm{a}}$ & 100 \\
\hline Formulated P & $0.80 \pm 0.06^{\mathrm{cd}}$ & 80 & $0.88 \pm 0.05^{d}$ & 74 & $0.71 \pm 0.06^{\mathrm{cd}}$ & 82 \\
\hline Formulated $\mathrm{P}+$ wheat germ & $0.93 \pm 0.06^{\mathrm{abc}}$ & 93 & $1.02 \pm 0.07^{b c}$ & 86 & $0.86 \pm 0.06^{a b}$ & 99 \\
\hline$L S D$ & 0.120 & & 0.119 & & 0.092 & \\
\hline
\end{tabular}

$P=$ Pesticide (Profenofos). \% relative to normal healthy control. Values are expressed as means $\pm S D(n=6)$.

Values with different superscript letters within the same column are significantly different $(P<0.05)$. 
Table 5

The glucose-6-phsphate dehydrogenase (G6PD) activity in different organ tissues of the experimental male albino rats

\begin{tabular}{|c|c|c|c|c|c|c|}
\hline \multirow{3}{*}{ Treatments } & \multicolumn{6}{|c|}{ G6PD activity (pmol of NADPH.H ( $^{+} / \mathrm{min} / \mathrm{mg}$ protein) } \\
\hline & \multicolumn{2}{|l|}{ Liver } & \multicolumn{2}{|l|}{ Brain } & \multicolumn{2}{|l|}{ Kidneys } \\
\hline & Values \pm SD & $\%$ & Values \pm SD & $\%$ & Values \pm SD & $\%$ \\
\hline Normal healthy control & $98.0 \pm 5.11^{\mathrm{ab}}$ & 100 & $71 \pm 4.17^{\mathrm{a}}$ & 100 & $30.1 \pm 2.06^{\mathrm{ab}}$ & 100 \\
\hline Normal healthy + wheat germ & $100.3 \pm 7.35^{\mathrm{a}}$ & 102 & $71 \pm 3.61^{a}$ & 100 & $31.0 \pm 2.00^{a}$ & 103 \\
\hline \multicolumn{7}{|l|}{ Oral } \\
\hline Technical P & $78.9 \pm 4.20^{\mathrm{de}}$ & 81 & $57.0 \pm 3.91^{\mathrm{de}}$ & 80 & $21.8 \pm 1.56^{\mathrm{e}}$ & 72 \\
\hline Technical+wheat germ & $91.0 \pm 5.77^{\mathrm{abc}}$ & 93 & $66.0 \pm 4.83^{\mathrm{abc}}$ & 93 & $27.2 \pm 1.99^{\mathrm{bcd}}$ & 90 \\
\hline Formulated P & $71.2 \pm 3.91^{\mathrm{e}}$ & 73 & $50.5 \pm 3.00^{\mathrm{e}}$ & 71 & $18.4 \pm 0.99^{f}$ & 61 \\
\hline Formulated $\mathrm{P}+$ Wheat germ & $88.1 \pm 6.61^{\mathrm{bcd}}$ & 90 & $63.3 \pm 3.82^{\mathrm{bcd}}$ & 89 & $24.1 \pm 1.60^{\mathrm{de}}$ & 80 \\
\hline \multicolumn{7}{|l|}{ Dermal } \\
\hline Technical P & $80.9 \pm 6.54^{\text {cde }}$ & 83 & $63.1 \pm 4.01^{\mathrm{bcd}}$ & 89 & $25.1 \pm 1.91^{c d}$ & 83 \\
\hline Technical $\mathrm{P}+$ wheat germ & $93.1 \pm 7.26^{\mathrm{ab}}$ & 95 & $69.3 \pm 4.51^{\mathrm{ab}}$ & 98 & $28.3 \pm 1.76^{\mathrm{ab}}$ & 94 \\
\hline Formulated $\mathrm{P}$ & $75.4 \pm 4.32^{e}$ & 77 & $59.0 \pm 3.61^{\mathrm{cd}}$ & 83 & $24.2 \pm 1.32^{\mathrm{de}}$ & 80 \\
\hline Formulated $\mathrm{P}+$ wheat germ & $92.1 \pm 6.90^{\mathrm{ab}}$ & 94 & $65.4 \pm 4.54^{\mathrm{abc}}$ & 92 & $27.3 \pm 1.04^{b c}$ & 91 \\
\hline$L S D$ & 10.10 & & 6.87 & & 2.87 & \\
\hline
\end{tabular}

$P=$ Pesticide (Profenofos). \% relative to normal healthy control. Values are expressed as means $\pm S D(n=6)$.

Values with different superscript letters within the same column are significantly different $(P<0.05)$.

(2003) and our previous findings (Abdel-Rahim, 2009 and Abdel-Rahim and Abdel-Rahim, 2008) which reported that respiratory mitochondria enzymes and glycolysis systems were changed by the ingestion of profenofos in rats but these effects were improved and treated with the feeding of an antioxidant diet. Also, Abdel-Rahim et al. (2009) reported that the blood total lipids, cholesterol, triglycerides and phospholipid contents were reduced in cypermethrin insecticide intoxicated

Table 6

The 6-phosphogluconate dehydrogenase (6PGD) activity in different organ tissues of the experimental male albino rats

\begin{tabular}{|c|c|c|c|c|c|c|}
\hline \multirow{3}{*}{ Treatments } & \multicolumn{6}{|c|}{ 6PGD activity (pmol of NADPH. + $^{+} / \mathrm{min} / \mathrm{mg}$ protein) } \\
\hline & \multicolumn{2}{|l|}{ Liver } & \multicolumn{2}{|l|}{ Brain } & \multicolumn{2}{|c|}{ Kidneys } \\
\hline & Values \pm SD & $\%$ & Values \pm SD & $\%$ & Values \pm SD & $\%$ \\
\hline Normal healthy control & $42.8 \pm 2.30^{a}$ & 100 & $80.2 \pm 5.11^{\mathrm{a}}$ & 100 & $33.2 \pm 2.03^{a}$ & 100 \\
\hline Normal healthy + wheat germ & $43.7 \pm 2.17^{\mathrm{a}}$ & 102 & $80.8 \pm 4.54^{\mathrm{a}}$ & 101 & $33.4 \pm 1.52^{\mathrm{a}}$ & 100 \\
\hline \multicolumn{7}{|l|}{ Oral } \\
\hline Technical P & $35.0 \pm 2.00^{\mathrm{bc}}$ & 82 & $62.9 \pm 4.37^{\mathrm{cd}}$ & 78 & $25.4 \pm 1.60^{\mathrm{a}}$ & 76 \\
\hline Technical+wheat germ & $40.9 \pm 3.12^{\mathrm{a}}$ & 96 & $75.2 \pm 4.73^{\mathrm{ab}}$ & 94 & $29.1 \pm 1.90^{\mathrm{a}}$ & 88 \\
\hline Formulated P & $27.82 \pm 1.91^{d}$ & 65 & $59.0 \pm 4.76^{d}$ & 74 & $21.9 \pm 1.40^{\mathrm{a}}$ & 66 \\
\hline Formulated $\mathrm{P}+$ Wheat germ & $40.43 \pm 3.20^{a}$ & 94 & $72.1 \pm 4.56^{\mathrm{ab}}$ & 90 & $26.3 \pm 1.98^{\mathrm{a}}$ & 79 \\
\hline \multicolumn{7}{|l|}{ Dermal } \\
\hline Technical P & $39.2 \pm 2.02^{\mathrm{ab}}$ & 92 & $70.5 \pm 5.05^{b c}$ & 88 & $28.8 \pm 1.95^{\mathrm{a}}$ & 87 \\
\hline Technical $\mathrm{P}+$ wheat germ & $42.1 \pm 3.48^{a}$ & 98 & $76.7 \pm 4.61^{\mathrm{ab}}$ & 96 & $29.7 \pm 1.68^{a}$ & 90 \\
\hline Formulated P & $34.0 \pm 2.03^{c}$ & 79 & $61.8 \pm 5.01^{d}$ & 77 & $25.1 \pm 1.37^{\mathrm{a}}$ & 76 \\
\hline Formulated $\mathrm{P}+$ wheat germ & $41.1 \pm 2.90^{\mathrm{a}}$ & 96 & $74.0 \pm 5.07^{\mathrm{ab}}$ & 92 & $27.2 \pm 2.12^{\mathrm{a}}$ & 82 \\
\hline$L S D$ & 4.39 & & 8.15 & & 3.02 & \\
\hline
\end{tabular}

$P=$ Pesticide (Profenofos). \% relative to normal healthy control. Values are expressed as means $\pm S D(n=6)$.

Values with different superscript letters within the same column are significantly different $(P<0.05)$. 
rats, but these effects were improved by feeding an antioxidant diet (guava and wheat germ).

G6PD and 6PGD were considered the fundamental enzymes of pentose phosphate pathway activity. The primary results of the pathway are: the generation of reducing equivalents, in the form of NADPH (accounting for approximately $60 \% \mathrm{NADPH}$ production), used in reductive biosynthesis reactions within cells (e.g. fatty acid synthesis) and production of ribose-5-phosphate (R5P), used in the synthesis of nucleotides and nucleic acids (Kruger and von Schaewen, 2003). The inhibition of nucleotide biosynthesis, i.e. formation of ribose component and the phosphorylation of ribonucleotides inhibited protein biosynthesis (Abdel-Rahim and AbdelRahim, 2007 and Abdel-Rahim, 2009). The obtained results of the present experiment may suggest that the relationship between the pentose phosphate pathway and fatty acids causing triglyceride biosynthesis (i.e. the using of NADPH. $\mathrm{H}^{+}$in the reduction system of cell fatty acid synthesis) disappeared and produced NADPH. $\mathrm{H}^{+}$ from the pentose phosphate pathway was utilized for energy production instead of the normal pathway. This may be due to the fact that the ingestion of the insecticides produced hypoxia for intoxicated animals (Lukaszewicz-Hussain, 2001 and Lukaszewicz-Hussain and MoniuszkoJakoniuk, 2003).

The present results are in agreement with those of Karaoz et al. (2002); Kaur and Dhanju (2005); Abdel-Rahman et al. (2006) and Kamath et al. (2008), who showed that organophosphorus insecticide intoxications have been reported to potentate the biological activity in the lipid profiles of the animal tissues. Although the liver is the main site of metabolic activation of toxic chemicals, recent attention has been paid to extrahepatic organs which are often targets for xenobiotics. In addition to the liver, the brain and kidneys are involved in the metabolism of xenobiotics and contribute to the overall toxic profile of a toxicant although typically much less than the liver (Mahboob et al., 2004). In connection with the treatments with antioxidant agents such as vitamins ( $\alpha$-tocopherol: Vit. E), attenuated xenobiotic induced biochemical cell perturbation has several ways to alleviate the effect of the oxidative stress produced by pesticides, either by repairing the damage (lipid peroxidation by-products) or by directly reducing the pro-oxidative state via enzymatic and non-enzymatic antioxidants. Nonenzymatic (vitamin E, A and C etc) and enzymatic (superoxide dismutase, glutathione peroxidase and catalase etc) antioxidants have been shown to scavenge free radicals (Stephen et al., 1997 and Karaoz et al., 2002). Wheat germ contains the highest tocopherol content of all vegetable oil, and also the highest content of $\alpha$-tocopherol, which represents around $60 \%$ of the total content (Piras et al., 2009). Also, wheat germ has high contents of minerals including $\mathrm{Zn}, \mathrm{Fe}, \mathrm{K}$ and $\mathrm{P}$ as well as protein, lipid, dietary fibers, carotenoids, carbohydrate and other vitamins (Pennington, 1989 and Ibrahim et al., 1990). Vitamins $A$ and $E$ are most important among many low molecular weight compounds which can act as biological antioxidants (Karaoz et al., 2002; Lukaszewicz-Hussain and MoniuszkoJakoniuk, 2003 and Abdel-Rahim and AbdelRahim, 2007). Recent findings indicate that the toxic manifestation induced by organophosphorus insecticides may by associated with the enhanced production of reactive oxygen species (ROS), which gives an explanation for why ROS is proposed to be caused by a mechanism in which the xenobiotic toxicant and pathological conditions may produce oxidative stress and induce various tissue damage (Dwivedi et al., 1998 and AbdelRahman et al., 2006).

ROS may interact with cellular protein, lipid and DNA causing alterations in the target cell function. Acute oxidative injury may produce selective cell death and a compensatory increase in cell proliferation (Stephen et al., 1997 and Klaunig et al., 1998). Thus, the administration of wheat germ rich diets (containing vitamins $E$ and $A$ and other antioxidants) was shown to protect various biomolecules, such as DNA, membrane lipids and cytosolic proteins from oxidative damage induced by oxygen-derived free radicals (Karaoz et al., 2002; Goel et al., 2007 and Verma et al., 2007).

The decrease in lipids and lipid fractions in the liver, brain and kidneys of rats after long-term induction with $1 / 20 L_{50}$ of profenofos indicated degenerative changes. All organophosphorus pesticides (OP) are lipophilic and these environmental xenobiotics are known to have a strong affinity for interaction with membrane phospholipids, and the phospholipid component of the biomembrane is believed to be the site of action of OP insecticides with the formation of ROS; and one of the targets of creative oxygen-induced injury is lipid peroxidation. Thus, in addition to acetylcholinesterase being the principal mode of action of OP pesticides, increased lipid peroxidation and altered enzyme activity have also been implicated in mediating OP toxicity in animals (Kaur and Dhanju, 2005).

In connection with oxidative pentose phosphate shunt G6PD and 6PGD are the key enzymes of this pathway which is responsible for the generation of $\mathrm{NADPH} . \mathrm{H}^{+}$. These enzymes play essential roles in the regulation of oxidative stress by regulating $\mathrm{NADPH} . \mathrm{H}^{+}$level, the main intracellular reductant. For this reason, both enzymes are required for the antioxidant defence system (Salvemini et al., 1999 and Zhang et al., 2000). G6PD and 6PGD catalyze the first steps in the pentose phosphate pathway, oxidizing glucose-6-phosphate to 6-phosphogluconate, which is then oxidized to 3-keto 6-phosphogluconate, reducing 2 molecules of $\mathrm{NADP}^{+}$to $\mathrm{NADPH} . \mathrm{H}^{+}$ (Murray et al., 2006). The NADPH, in turn, maintains the supply of reduced glutathione in the cells which is used to mop up free radicals that cause oxidative damage (Mehta et al., 2000). In the case of genetic G6PD and 6PGD deficiency, or 
other circumstances where NADPH. $\mathrm{H}^{+}$is in short supply, the reduction of G-S-S-G is impaired; there is a deficiency of GSH and hemolytic anemia (Parke and Piotrowski, 1996). It has been recently suggested that the primary physiological role of G6PD in mammalian cells is the defense against oxidative stress injury. The formation of GSH from its oxidized form (G-S-S-G) is dependent on $\mathrm{NADPH} . \mathrm{H}^{+}$produced by the pentose phosphate pathway. This pathway can be activated in response to GSH depletion (Salvemini et al., 1999 and Karaoz et al., 2002). As is reported by some authors the activities of G6PD, 6PGD and glutathione peroxidase (GPx) are linked in their capacity to prevent peroxidative tissue damage from oxidants. GPx converts toxic lipid hydroperoxides and $\mathrm{H}_{2} \mathrm{O}_{2}$ using reducing equivalents generated by the oxidative shunt of the pentose phosphate pathway (Bus et al., 1978; Frei et al., 1989 and Lukaszewicz-Hussain and Moniuszko-Jakoniuk, 2003).

\section{CONCLUSIONS}

The present results suggest that profenofos decreases the lipid profile and G6PD and 6PGD activities which may cause depletion of NADPH. $\mathrm{H}^{+}$, which is the main intracellular reductant; but that feeding a wheat germ rich diet (rich source of vitamin E) considerably reduces the effects of profenofos on the liver, brain and kidney tissues of profenofos-induced rats. Generally, profenofos caused extensive biochemical injury. Such effects were relevant to the amount of dose given (AbdelRahman et al., 2006), which were alleviated by the antioxidant agents of the wheat germ rich diet.

\section{REFERENCES}

Abdel-Rahim EA and Abdel-Rahim GA. 2007. The hypointensive effects of carrot as a natural antioxidant on chlorpyrifos toxicity, nucleic acids and chromosomal aberration in albino rats. Egypt. J. Appl. Sci. 22, 427-444.

Abdel-Rahim EA and Abdel-Rahim GA. 2008. Biochemical effects of guava diet antioxidant as a hypointensive agent for dimethoate toxicity on energy and cytochrome- c respiratory system in the pesticide albino rats. J. Biol. Chem. Environ. Sci. 3, 111-126.

Abdel-Rahim EA, Abdel-Rahim GA, Fayed SA and Mahmoud GI. 2009. Antioxidant diet as protective agents against biochemical perturbation effects induced by cypermethrin on lipids and protein fractions as well as kidneys function of blood rat. Aust. J. Basic Appl. Sci. 3, 267-276.

Abdel-Rahim GA. 2009. Reduction of profenofos toxicity effects by $\alpha$-tocopherol diet (wheat germ) on carbohydrate metabolism of male albino rats. Egypt. J. Nutr. 24, 1-24.

Abdel-Rahman GH, Farrag AR, El Sharkawy SL and Abdel-Aal WE. 2006. Effects of profenofos on antioxidant enzymes activities and gastric mucosa in rats. JASMR 1, 125-134.
Abdollahi M, Ranjbar A, Shadnia S, Nikfar S and Rezaiee A. 2004. Pesticides and oxidative stress a review. Med. Sci. Monit. 106, 141-147.

Abou-Zeid MM, El-Baroty G, Abdel-Rahim EA, Blankato J, Dary C, El-Sebae AH and Saleh MA. 1993. Malathion disposition in dermally and orally treated rats and impact on the blood serum acetylcholinesterase and protein profile. J. Environ. Sci. Health 828, 413-430.

Bradford MM. 1976. A rapid and sensitive method for the quantitation of microgram quantities of protein utilizing the principle of protein-dye binding. Anal. Biochem. 72, 248-254.

Bus JS, Vinegar A and Brooks SM. 1978. Biochemical and physiological changes in lungs of rats exposed to a cadmium chloride aerosol. Am. Rev. Respir. Disease 118, 573-584.

Chaurchami AJ, Miller W and Adstein JDB. 1959. Determination of total and free cholesterol. Clin. Chem. 5 609-611.

Coskum O, Kanter M, Korkmaz A and Oter S. 2005. Quercetin, a flavonoid antioxidant, prevents and protects streptozotocin-induced oxidative stress and $\beta$-cell damage in rat pancreas. Pharmacol. Res. 51, 117-123.

COT. 1999. Organophosphates (Committee on toxicity of chemicals in food, consumer products and the Environmental) London, UK, Department of Health.

Dwivedi PD, Mukul D and Khanna SK. 1998. Role of cytochrome P-450 in quinalphos toxicity: Effect on hepatic and brain antioxidant enzymes in rats. Food Chem. Toxicol. 36, 437-444.

Fisher WT, Edwards NM and Lehman RW. 1964. Simplified assay of vitamins $A$ and $E$ in mixtures. $J$. Pharm. Sci. 53, 294-298.

Frei $B$, England L and Ames BN. 1989. Ascorbate is an outstanding antioxidant in human blood plasma. Proc. Natl. Acad. Sci. USA 86, 6377-6381.

Glock GE and McLean P. 1953. Further studies on the properties and assay of glucose-6-phosphate dehydrogenase and 6-phosphogylconate dehydrogenase of rat liver. Biochem. J. 55, 400-408.

Goel A, Dani V and Dhawan DK. 2005. Protective effects of zinc on lipid peroxidation antioxidant enzyme and hepatic histoarchitecture in chlorpyrifos-induced toxicity. Chem. Biol. Interact. 156, 131-140.

Goel A, Dani V and Dhawan DK. 2007. Zinc mediates normalization of hepatic drug metabolizing enzymes in chlorpyrifos-induced toxicity. Toxicol. Letters 169, 26-33.

Grover P, Danadevi K, Mahboob M, Rozati B, Saleha B and Rahman MF. 2003. Evaluation of genetic damage in workers employed in pesticide production utilizing the comet assay. Mutagenesis 18, 201-205.

Hayes JD, Flanagan JU and Jowsey IR. 2005. Glutathione transferases. Annu. Rev. Pharmacol. Toxicol. 45, 51-88.

Ibrahim AM, Zaid MA, El-Maholy LD and Abou-Zeid MM. 1990. Studies on crude wheat germ produced as a by-product of milling industry. Ann. Agric. Sci. Moshtohor 28, 1189-1200.

Jacob RA and Burri BJ. 1996. Oxidative damage and defense. Am. J. Clin. Nutr. 63, 985S-990S.

Joseph RK, Shauma A and Ames M. 1972. Determination of total lipid in blood serum. Powl. Clin. Chem. 18, 199-201.

Kamath V, Joshi AKR and Rajini PS. 2008. Dimethoate induced biochemical perturbations in rat pancreas and its attenuation by cashew nut skin extract. Pesticide Biochem. Physiol. 90, 58-65. 
Karaoz E, Gultekin F, Akdogan M, Oncu M and Gokciman A. 2002. Protective role of melatonin and a combination of vitamin $\mathrm{C}$ and vitamin $\mathrm{E}$ on lung toxicity induced by chlorpyrifos-ethyl in rats. Exp. Toxic. Pathol. 54, 97-108.

Kaur S and Dhanju CK. 2005. Biochemical effects of some organophosphorus pesticides on the ovaries of albino rats. Indian J. Physiol. Pharmacol. 49, 148-152.

Ketes M. 1972. Techniques of lipidology. Isolation, analysis and identification of lipids. Amsterdam: North Holland and Publishing Co.

Klaunig JE, Xu Y, Isenberg JS, Bachowski S, Kolaja KL, Jiang J, Stevenson DE and Walborg EF. 1998. The role of oxidative stress in chemical carcinogenesis. Environ. Health Prospect. 106 289-295.

Kruger NJ, von Schaewen A. 2003. The oxidative pentose phosphate pathway: structure and organisation. Curr. Opin. Plant Biol. 6, 236-46.

Lane-Peter WA and Pearson AE. 1971. Dietary requirements In: The Laboratory Animal Principles and Practice. pp. 142. Academic press. London and New York.

Leenhardt F, Fardet A, Lyan B, Gueux E, Rock E, Mazur A, Chanliaud E, Demignè C and Rèmésy C. 2008. Wheat germ supplementation of a low vitamin $E$ diet in rats affords effective antioxidant protection in tissues. J. Am. Coll. Nutr. 27, 222-228.

Lukaszewicz-Hussain A. 2001. Organophosphate insecticide chlorfenvinphos affects superoxide dismutase, catalase and malondialdehyde in rat liver. Polish J. Environ. Studies 10, 279-282.

Lukaszewicz-Hussain A and Moniuszko-Jakoniuk J. 2003. Organphosphate insecticide chlorfenvinphos affects enzymatic and non-enzymatic antioxidants in erythrocytes and serum of rats. Polish J. Environ. Studies 12, 417-423.

Mahboob M, Kaleem M and Siddiqui J. 2004. Effects of a noval organophosphorus pesticide (RPR-V) on extra hepatic detoxifying enzymes after repeated oral doses in rats. Toxicol. 202, 159-164.

Mehta A, Mason PJ, Vulliamy TJ. 2000. Glucose-6phosphate dehydrogenase deficiency. Baillieres Best Pract. Res. Clin. Haematol. 13, 21-38.

Middle Brooks J. 1977. Statistical calculation. How to solve statistical problem. Annals Arboreum Science 62, 21-27.

Murray RK, Grennerm DK, Mayes PA and Rodwell VW. 2006. Harper's illustrated biochemistry $\left(27^{\text {th }}\right.$ ed) McGraw Hill Comp. Inc. Boston, New York, Singapora.

Noguchi C and Nikki E. 2000. Phenolic antioxidants: a rationale for design and evaluation of novel antioxidant drug for atherosclerosis. Free Rad. Biol. Med. 28, 1538-1546.
Ohkatsu Y, Kajiyama T and Arai Y. 2001. Antioxidant activities of tocopherols. Polym. Degrad. Stabil. 72, 303-311.

Oral B, Guney M, Demirin H, Ozguner M, Giray SG, Take G, Mungan T and Altuntas I. 2006. Endometrial damage and apoptosis in rats induced by dichlorvos and ameliorating effect of antioxidant vitamin $\mathrm{E}$ and C. Reprod. Toxicol. 22, 783-790.

Parke DV and Piotrowski JK. 1996. Glutathione: its role in detoxication of reactive oxygen species and environmental chemicals. Acta Pol. Toxicol. 4, 1-14.

Pennington JA. 1989. Food values of portions commonly used. (15th ed). Perennial Library, Harper and Row Publishers. Inc. New York, pp. 104 and 282.

Piras A, Rosa A, Falconieri D, Porcedda S, Dessì MA and Marongiu B. 2009. Extraction of oil from wheat germ by supercritical $\mathrm{CO}_{2}$. Molecules 14, 2573-2581.

Ray DE and Richards PG. 2001. The potential for toxic effects of chronic, low-dose exposure to organophosphates. Toxicol. Lett. 12, 343-351.

Rohrer A, Hiaber TE, Melnyk LJ and Berry MR. 2003. Transfer efficiencies of pesticides from household flooring surfaces to food. J. Expo. Anal. Environ. Epidemiol. 13, 454-464.

Salvemini F, Franze A, lervolino A, Filosa S, Salzano S and Ursini MV. 1999. Enhanced glutathione levels and oxidoresistance mediated by increased glucose6-phosphate dehydrogenase expression. J. Biol. Chem. 274, 2750-2757.

Stephen B, Kyle L, Yong X, Cynthia A, Donald L, Karl I and James L. 1997. Role of oxidative stress in the mechanism of dieldrin's hepatotoxicity. Ann. Clin. Lab. Sci. 27, 196-208.

Tomlin CDS. 2000. Pesticide Manual, A world compendium the pesticide manual (20th ed). British crop protection Council. pp. 230-231.

USEPA. 2000. Health and environmental affects profile for Dichlorvos U.S. Environmental Protection Agency. 11-15.

Verma RS, Mehta A and Srivastava N. 2007. In vivo chlorpyrifos induced ox idative stress: Attenuation by antioxidant vitamins. Pest. Biochem. Physiol. 88, 191196.

Young A and Pestaner DL. 1975. Determination of triglyceride in serum. Clin. Chem. 21, 5-7.

Zhang Z, Apse K, Pang J and Stanton RC. 2000. High glucose inhibits glucose-6-Phosphate dehydrogenase via cAMP in aortic endothelial cells. J. Biol. Chem. 275, 40042-40047.

Recibido: $11 / 12 / 10$ Aceptado: $25 / 1 / 11$ 